\title{
The Usage of E-Learning Model To Optimize Learning System In Higher Education by Using Dick and Carey Design Approach
}

\author{
Anak Agung Gde Satia Utama \\ Department of Accountancy, Economics and Business Faculty, Airlangga University \\ Jl. Airlangga 4-6,Surabaya \\ gde.agung@feb.unair.ac.id
}

\begin{abstract}
Nowadays many universities in the world apply technology enhanced learning in order to help learning activities. Due to the potentials technology enhanced learning offers, recent education using it and universities in particular are trying to apply it. One of the subjects of this research is The Accounting Department of Airlangga University in Surabaya. The idea of this research is to investigate the students about how they know deeply about e-learning system and learning objectives as a first step to conduct e-learning model. After the model completed, the next step is to prepare database learning. Entity Relationship Diagram (ERD) can help to explain the model. The purpose of this research was done by using Dick and Carey Design Model. There are nine steps to conduct e-learning model. All steps can be categorized into three steps research: first is the introduction or empirical study, the next step is the design and the last is the feedback after the implementation. The methodology used in this research is using Qualitative Exploratory, by using questionnaire and interviews as data collection techniques. The analysis of the data shows organization requires information about e-learning content, user as a learning subject and information technology infrastructures. E-learning model as one of the alternative learning can help users to optimized learning.
\end{abstract}

Keywords - E-learning Content, Database Learning, Entity Relationship Diagram, Dick and Carey Design, Elearning model and Optimize learning

Article history:

Received 26 February 2016; Received in revised form 19 April 2016 \& 24 April 2016; Accepted 26 April 2016; Available online 30 April 2016

\section{INTRODUCTION}

Information technology (IT) recently plays a critical and strategic role. The application of information technology is omnipresent, such as in economy, business, banking, engineering, social, culture, and so on (Erdani \& Yuliadi, 2007). The application of technology-based information system is also pervading educational environments, where education principally represents the processes of communication and information of the educator and the educated.

Educational institutions in Indonesia are currently competing for educational utilization of information and communication technology, for education by constructing hardware infrastructure, the Internet network development, software procurement, and so on (Arifin, 2007). Educational development towards e-learning is compulsory (Triono, 2007) and the need for concept of information technology-based teaching and learning is a requisite (Widodo, 2008). It is believed that improvement of education productivity can be achieved by using information technology (Witanti \& Wina, 2008). Students can download materials of lectures administered by lecturers through web sites of respective universities.

Rapid development of information technology supported by sophisticated technology creates opportunities for researchers to find solutions for organization problems. The advance of information system lead to the carrying out of educational researches, such as by (Wahid \& Fahul, 2007) and (Suryani, 2009) in Indonesia and by (Kurti, 2008) in Kosovo.

Research by (Wahid \& Fahul, 2007) concerned with analysis of factors influencing adoption and diffusion of Klasiber, a portal of e-learning. The approach employed in this study was the diffusion of Innovation Theory developed by Rogers. The purpose of the research was to implement elearning by using Learning Management Systems (LMS) of Moode open source subsequently called Klasiber.

Study by (Suryani, 2009) more concerned with the development of IT Governance in higher education institutions by referring to the standards of COBIT 4.0. One of the recent studies of elearning was conducted by (Kurti, 2008). The differences of this study and previous studies can be summarizes in table 1 . 
TABLE 1. SIMILARITIES AND DIFFERENCES OF PREVIOUS STUDIES AND PRESENT STUDY

\begin{tabular}{|c|c|c|c|c|}
\hline Aspects & Present study & $\begin{array}{c}\text { (Wahid \& Fahul, } \\
\text { 2007) }\end{array}$ & (Suryani, 2009) & (Kurti, 2008) \\
\hline Similarity & \multicolumn{4}{|c|}{$\begin{array}{l}\text { Equally deal with e-learning as special topic } \\
\text { Object of research is higher education institutions } \\
\text { Employ qualitative method } \\
\text { Use approach of some experts in analysis and construction of model }\end{array}$} \\
\hline Difference & Present study & $\begin{array}{c}\text { (Wahid \& Fahul, } \\
\text { 2007) }\end{array}$ & (Suryani, 2009) & (Kurti, 2008) \\
\hline Purpose & $\begin{array}{l}\text { Construct e- } \\
\text { learning model }\end{array}$ & $\begin{array}{l}\text { Analysis of e- } \\
\text { learning portal }\end{array}$ & $\begin{array}{l}\text { Development of IT } \\
\text { Governance model }\end{array}$ & Evaluation of e-learning model \\
\hline Process & $\begin{array}{l}\text { Dick and Carey } \\
\text { Design Model }\end{array}$ & $\begin{array}{c}\text { Diffusion of } \\
\text { Innovation Theory } \\
\text { by Rogers }\end{array}$ & $\begin{array}{c}\text { Standards of COBIT } \\
4.0\end{array}$ & Octagonal Model by Khan \\
\hline Respondent & $\begin{array}{c}\text { Lecturers and } \\
\text { students }\end{array}$ & Students & $\begin{array}{c}\text { All elements of } \\
\text { organization }\end{array}$ & $\begin{array}{l}\text { Students and (senior and } \\
\text { junior) lecturers }\end{array}$ \\
\hline Result & $\begin{array}{l}\text { E-learning model } \\
\text { without validity } \\
\text { test }\end{array}$ & $\begin{array}{c}\text { The Effect of } \\
\text { innovation on pace } \\
\text { of diffusion }\end{array}$ & $\begin{array}{c}\text { IT Governance } \\
\text { model with validity } \\
\text { test }\end{array}$ & $\begin{array}{c}\text { Differences in the viewpoint of } \\
\text { senior lecturers and junior } \\
\text { ones on IT utilization }\end{array}$ \\
\hline
\end{tabular}

There are many terminologies in today's education realm that have nearly the same connotations, namely web-base learning, online learning, computer-based learning and distance learning (Effendi \& Zhuang, 2005). Electronic learning (e-learning) is a special combination of technology, especially informatics and education (Setiawan, 2005).

Instructional materials are critical factors in developing e-learning materials. Consequently, a basic and clear principle of development is required. In doing so, a principle of Instructional Design can be used (Setiawan, 2005). Instructional Design is used to design, develop, evaluate, and refine an e-learning for higher education (Siragusa, 2006)

There are three (3) criterias for optimal utilization of the Internet technology in delivering learning (Rosenberg, 2001): (1) e-learning is a network with capability of updating, retaining, distributing, and allocating instructional material or information; (2) transmission to end-users through computer by means of standard Internet technology; (3) focus on broadest view on learning behind traditional learning paradigm.

In instructional designs, there are voluminous models that can be used to compose e-learningbased instructional materials (Botturi, Cantoni, Lepori, \& Tardini, 2006) (The Herridge Group Inc. , 2004). Among those models are (a) Morrison, Ross and Kemp who tend to class orientation, (b) Seels and Glasgow who are result-oriented, and (c) Dick and Carey who do not only focus on class and outcome but also overall system. Differences of the three models can be found in Table 2 and Table 3.

In general, the model of Dick and Carey underlying this research uses system of outlining overall learning processes in composing smaller parts, starting from determination of instructional purposes to its evaluation (Dick, Carey, \& Carey, 2001). The model design of Dick and Carey can be

TABle 2. Differences of Morrison, Seels, Dick and Carey Design Model (Dick, CARey, \& CARey, 2001)

\begin{tabular}{|c|c|c|c|}
\hline & $\begin{array}{l}\text { Morrison, Ross } \\
\text { and Kemp }\end{array}$ & Seels and Glasgow & Dick and Carey \\
\hline Orientation & Classroom & Product & System \\
\hline Approach & Holistic & Systematic & Systemic \& Systematic \\
\hline Primary Output & $\begin{array}{l}\text { A few hours of } \\
\text { instruction }\end{array}$ & An instructional package & Course or curriculum \\
\hline Goal & $\begin{array}{l}\text { Improve a piece } \\
\text { of content }\end{array}$ & Improve efficiency of production & Create an instructional system \\
\hline $\begin{array}{c}\text { Required level of } \\
\text { instructional design }\end{array}$ & Low & Medium to high & Low, medium, high \\
\hline $\begin{array}{c}\text { Level of front end } \\
\text { analysis }\end{array}$ & Minimal & Moderate & Extensive \\
\hline $\begin{array}{c}\text { Level of formative } \\
\text { evaluation }\end{array}$ & Moderate & $\begin{array}{c}\text { Moderate in overall model but } \\
\text { extensive in the materials development } \\
\text { phase }\end{array}$ & Extensive throughout \\
\hline $\begin{array}{c}\text { Project management } \\
\text { focus }\end{array}$ & Strong & $\begin{array}{c}\text { Strong. This model is organized into } \\
\text { three separate project management } \\
\text { phase }\end{array}$ & Strong \\
\hline Learner focus & Strong & $\begin{array}{c}\text { Moderate. Learner characteristics are } \\
\text { taken into account during analysis } \\
\text { phase }\end{array}$ & $\begin{array}{c}\text { Moderate. Learner characteristics are } \\
\text { taken into account during analysis } \\
\text { phase }\end{array}$ \\
\hline
\end{tabular}




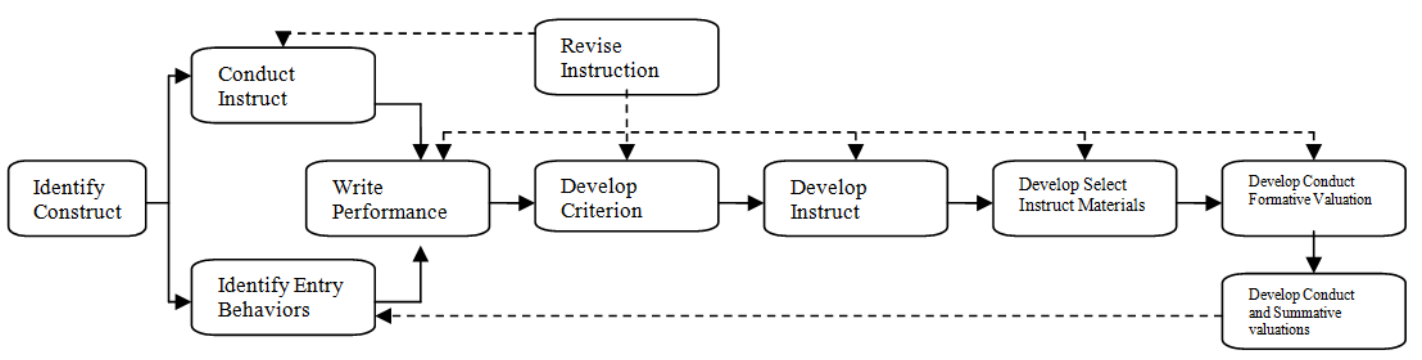

Figure 1. Dick and Carey Design Model (Dick, Carey, \& Carey, 2001)

TABle 3. Comparability of Morrison, Glasgow And Dick CAREy Related to E-LEARning (Dick, CAREy, \& CAREy, 2001)

\begin{tabular}{|c|c|c|c|}
\hline & Morrison, Ross and Kemp & Seels and Glasgow & Dick and Carey \\
\hline $\begin{array}{l}\text { Ability to apply phases } \\
\text { steps iteratively }\end{array}$ & $\begin{array}{l}\text { The design of the model } \\
\text { allows for the iterative } \\
\text { application of phases and } \\
\text { steps }\end{array}$ & $\begin{array}{c}\text { Whitin each of three phases } \\
\text { the steps can be applied } \\
\text { iteratively. There is some } \\
\text { flexibility for overlapping the } \\
\text { phases. }\end{array}$ & $\begin{array}{l}\text { Once the instructional goal } \\
\text { has been established the other } \\
\text { phases can be applied } \\
\text { iteratively }\end{array}$ \\
\hline $\begin{array}{l}\text { Focus on instructional } \\
\text { strategy \& media selection }\end{array}$ & $\begin{array}{l}\text { This model allows for } \\
\text { instructional strategies and } \\
\text { media to be selected before } \\
\text { the content is analyzed since } \\
\text { one can start any phase. } \\
\text { However, one can choose to } \\
\text { analyze the content first }\end{array}$ & $\begin{array}{l}\text { Selection of instructional } \\
\text { strategy takes place in some } \\
\text { project phase as analysis }\end{array}$ & $\begin{array}{l}\text { Media selection is strongly } \\
\text { linked to instructional } \\
\text { strategies and both are based } \\
\text { on learning objectives, } \\
\text { context, and content being } \\
\text { addressed. }\end{array}$ \\
\hline $\begin{array}{l}\text { Structure: positioning and } \\
\text { sequencing of content }\end{array}$ & \multicolumn{3}{|c|}{$\begin{array}{l}\text { All three models contain an instructional strategy step in which diverse options for positioning } \\
\text { and sequencing can be considered. }\end{array}$} \\
\hline Content Design & \multicolumn{3}{|c|}{ All three models have steps or phases in which content design addressed } \\
\hline Motivation and feedback & \multicolumn{3}{|c|}{$\begin{array}{l}\text { All three models support motivational and feedback approaches and mechanism. The rigor of } \\
\text { the three models may ensure that the required level of detail is available to make solid design } \\
\text { decisions. }\end{array}$} \\
\hline $\begin{array}{l}\text { Interaction and } \\
\text { involvement }\end{array}$ & \multicolumn{3}{|c|}{$\begin{array}{l}\text { The level of interaction and the degree of learner involvement are a design decisions that taken } \\
\text { in the instructional strategy phase of each of the models. These decisions would then inform } \\
\text { decisions related to the selection of instructional media. }\end{array}$} \\
\hline
\end{tabular}

found in Figure 1.

Based on the above background, the present research has two statements of the problem, namely: To construct models of e-learning and database learning and Creating e-learning model appropriate to achieve optimal learning in higher education institutions by using Dick and Carey model.

\section{RESEARCH METHODOLOGY}

\section{A. Type of Study}

The present research uses the methodology of qualitative approach. The method employed is exploratory research. Research using qualitativeexploratory approach is extensively carried out to inform an innovation; for example, detailed study of web-based learning environment (Agostinho, 2005).

\section{B. Data and Sampling}

Data collection in this qualitative-exploratory research used interview and documentation. Detailed technique of data collection can be found in Table 4.

\section{Stages of Research}

Based on the method and theory mentioned

TABle 4. TeChNique of Data Collection

\begin{tabular}{|c|c|c|c|c|}
\hline Technique & Data & Total Respondence & $\begin{array}{c}\text { Total Question } \\
\text { Place to collect } \\
\text { data }\end{array}$ \\
\hline Doccumentation & $\begin{array}{c}\text { GBPP, SAP, } \\
\text { Syllabus/lesson contract, } \\
\text { Undergraduate program } \\
\text { book system and Web }\end{array}$ & - & - & $\begin{array}{c}\text { Accounting } \\
\text { Department }\end{array}$ \\
\hline Interview & $\begin{array}{c}\text { Interview with questions } \\
\text { list. }\end{array}$ & $\begin{array}{c}\text { Accounting Department } \\
\text { and 2 student of S1 } \\
\text { Accounting }\end{array}$ & $\begin{array}{c}25 \text { questions to lecturers } \\
\text { and 16 questions to } \\
\text { students }\end{array}$ & $\begin{array}{c}\text { Economic Faculty } \\
\text { Airlangga } \\
\text { University }\end{array}$ \\
\hline Questioner & $\begin{array}{c}\text { Questioner with Multiple } \\
\text { choices }\end{array}$ & $\begin{array}{c}\text { Spread questionnaires } \\
\text { amount 50 to lecturers } \\
\text { and } 60 \text { to students }\end{array}$ & $\begin{array}{c}17 \text { questions to lecturers } \\
\text { and 19 questions to } \\
\text { students }\end{array}$ & $\begin{array}{c}\text { Economic Faculty } \\
\text { Airlangga } \\
\text { University }\end{array}$ \\
\hline
\end{tabular}


TABle 5. InPut-Process-OUtPut to CONSTRUCT E-LEARNING MOdEL

\begin{tabular}{|c|c|c|c|c|}
\hline Step & INPUT & PROCESS & OUTPUT & TOOLS \\
\hline Introduction & $\begin{array}{l}\text {-GBPP } \\
\text {-SAP } \\
\text {-Syllabus/lesson contract } \\
\text {-Web UNAIR }\end{array}$ & $\begin{array}{l}\text { 1. Formulate objectives } \\
\text { learning. } \\
\text { 2. Define participant of } \\
\text { learning. } \\
\text { 3. Organization need } \\
\text { analysis and } \\
\text { infrastructures that } \\
\text { related with e- } \\
\text { learning } \\
\text { implementation }\end{array}$ & $\begin{array}{l}\text { 1. Objectives, } \\
\text { participant and } \\
\text { learning module. } \\
\text { 2. Transfer learning } \\
\text { technique. } \\
\text { 3. Learning process }\end{array}$ & $\begin{array}{l}\text { - Interview } \\
\text { - Documentation } \\
\text { - Questioner } \\
\text { Tools Helping: Interview } \\
\text { guidelines, MP3 recorder, } \\
\text { Writing tools and Note } \\
\text { paper, SPSS 11,5 } \\
\text { (descriptive analysis). }\end{array}$ \\
\hline Design & $\begin{array}{l}\text { 1. Objectives, participant } \\
\text { and learning module. } \\
\text { 2. Transfer learning } \\
\text { technique. } \\
\text { 3. Learning process }\end{array}$ & $\begin{array}{l}\text { 1. Define e-learning } \\
\text { content. } \\
\text { 2. Make database } \\
\text { learning } \\
\text { 3. Construct entity } \\
\text { relationship. }\end{array}$ & $\begin{array}{l}\text { 1. Content e-learning } \\
\text { 2. E-learning Model } \\
\text { 3. Database Learning }\end{array}$ & $\begin{array}{l}\text { - Interview } \\
\text { - Questioner } \\
\text { - Chart/Diagram } \\
\text { Tools Helping: } \\
\text { Interview guidelines, MP3 } \\
\text { recorder, Ms Visio 2003 } \\
\text { to make chart, DFD, } \\
\text { Diagram, Ms Access to } \\
\text { design database and } \\
\text { SPSS } 11,5\end{array}$ \\
\hline Feedback & $\begin{array}{l}\text { Model and Database E- } \\
\text { learning }\end{array}$ & $\begin{array}{l}\text { E-learning model trial } \\
\text { and test in one subject } \\
\text { with assumption that } \\
\text { model has been } \\
\text { translated to computer } \\
\text { software. This research } \\
\text { didn't do that. }\end{array}$ & $\begin{array}{l}\text { E-learning } \\
\text { applications }\end{array}$ & Experiment in small class \\
\hline
\end{tabular}

above, processes of research aim at producing an e-learning model can be summarized as follows:

1. Observation stage

2. The model construction stages

The above overall stages could be made into table of input-process-output as can be found in table 5 .

\section{RESULTS}

A. The Overview of Information System in Accounting Department of Airlangga University

Information system of Airlangga University was interconnected to information systems of respective faculties, one of them was Faculty of Economy of Airlangga University. Hence,

TABLE 6. AChiEVEd OutPut of GBPP, Syllabus, SAP AND EduCATION Guidelines

\begin{tabular}{|c|c|c|c|c|c|}
\hline Source & Objectives Learning & $\begin{array}{c}\text { Learning } \\
\text { Participant }\end{array}$ & Learning Topic & $\begin{array}{c}\text { Transfer } \\
\text { Learning } \\
\text { Techniques }\end{array}$ & $\begin{array}{c}\text { Learning } \\
\text { Evaluation }\end{array}$ \\
\hline $\begin{array}{c}\text { GBPP } \\
\text { (Management } \\
\text { Information } \\
\text { Systems) }\end{array}$ & $\begin{array}{l}\text { The students will } \\
\text { understand about } \\
\text { management } \\
\text { information systems } \\
\text { and be able to make } \\
\text { paper based on MIS } \\
\text { chapter. }\end{array}$ & $\begin{array}{c}\text { Accounting } \\
\text { majority student } \\
\text { semester } 6 \text { that } \\
\text { pass Accounting } \\
\text { Information } \\
\text { System. }\end{array}$ & $\begin{array}{l}\text { Divided into } \\
\text { several chapters } \\
\text { in text book and } \\
\text { will be adjust to } \\
\text { amount of } \\
\text { meeting. }\end{array}$ & $\begin{array}{l}\text { Speech, Class, } \\
\text { presentation and } \\
\text { discussion. }\end{array}$ & $\begin{array}{l}\text { Writing test (middle, } \\
\text { final test), Daily } \\
\text { examination, } \\
\text { discuss, project } \\
\text { report, paper, and } \\
\text { presentation. }\end{array}$ \\
\hline $\begin{array}{c}\text { Syllabus/ } \\
\text { kontrak } \\
\text { perkuliahan }\end{array}$ & $\begin{array}{l}\text { Objectives learning } \\
\text { that students reach to } \\
\text { pass subject. }\end{array}$ & $\begin{array}{c}\text { Accounting } \\
\text { majority student } \\
\text { semester } 6 \text { that } \\
\text { pass Accounting } \\
\text { Information } \\
\text { System. }\end{array}$ & Summary of SAP & $\begin{array}{l}\text { Speech, class } \\
\text { presentation and } \\
\text { discussion. }\end{array}$ & $\begin{array}{l}\text { Writing test (middle, } \\
\text { final test), Daily } \\
\text { examination, } \\
\text { discuss, project } \\
\text { report, paper, and } \\
\text { presentation }\end{array}$ \\
\hline SAP & $\begin{array}{c}\text { Divided into general } \\
\text { and specific } \\
\text { objectives }\end{array}$ & $\begin{array}{c}\text { Accounting } \\
\text { majority student } \\
\text { semester } 6 \text { that } \\
\text { pass Accounting } \\
\text { Information } \\
\text { System. } \\
\end{array}$ & $\begin{array}{l}\text { Detail and more } \\
\text { specific } \\
\text { including activity } \\
\text { and step of } \\
\text { learning. }\end{array}$ & $\begin{array}{l}\text { Speech, Class, } \\
\text { presentation and } \\
\text { discussion. }\end{array}$ & $\begin{array}{l}\text { Writing test (middle, } \\
\text { final test), Daily } \\
\text { examination, } \\
\text { discuss, project } \\
\text { report, paper, and } \\
\text { presentation } \\
\end{array}$ \\
\hline
\end{tabular}


TABLE 7. E-LEARNING CONTENT

\begin{tabular}{|c|c|}
\hline & E-learning Content \\
\hline 1. Instructional Goal & $\begin{array}{l}\text { - Vision of learning. } \\
\text { - Objectives learning that students get knowledge to understand and implement. } \\
\text { - Step of learning: make syllabus, SAP, lesson contract,GBPP, media, tools. }\end{array}$ \\
\hline 2. Instructional Analysis & $\begin{array}{c}\text { - Tools to reach objectives learning: forum, discuss, student exercise. } \\
\text { - Example based on theory and practice. } \\
\text { - Define evaluation method. }\end{array}$ \\
\hline $\begin{array}{l}\text { 3. Entry behavior and } \\
\text { characteristics }\end{array}$ & $\begin{array}{l}\text { - Using Information Technology (IT) is not just help tools. } \\
\text { - Change learning style. } \\
\text { - IT needs. } \\
\text { - Challenge IT: Human Resources. } \\
\text { - How to fill IT. } \\
\text { - IT implementation. } \\
\text { - Self motivation. }\end{array}$ \\
\hline 4. Write performance objectives & - Success of learning : achieved objectives learning \\
\hline 5. Criterion referenced test items & $\begin{array}{l}\text { - Lecturer evaluation: questioner } \\
\text { - Discuss about case or test }\end{array}$ \\
\hline 6. Instructional strategy & $\begin{array}{l}\text { - Learning method: discuss, textbook. } \\
\text { - Change from manual basis to IT } \\
\text { - Motivated. }\end{array}$ \\
\hline 7. Instructional material & Technology infrastructures: internet. \\
\hline 8. Formative evaluation & Student evaluation: middle test, final test, Quiz, \\
\hline 9. Summative evaluation & Learning process evaluation and the importance of it for implementation. \\
\hline
\end{tabular}

Accounting Department together with departments received facilities of information system in order to provide services: SMS, hot spot, inter-computer network, an online study plan programming was used by undergraduate students of Accounting in order to program subjects of study, class lectures using computers or laptops, and LCD. Fundamental reason for selecting Accounting Department as the place for doing research was to initiate designing e-learning in a smaller scope by utilizing the available university website.

\section{B. Data Presentation}

Data of the research originated from interviews with lecturers or structural officials in Accounting Department and students of Accounting Department.

\section{Discussion}

The obtained four sources of documentation,

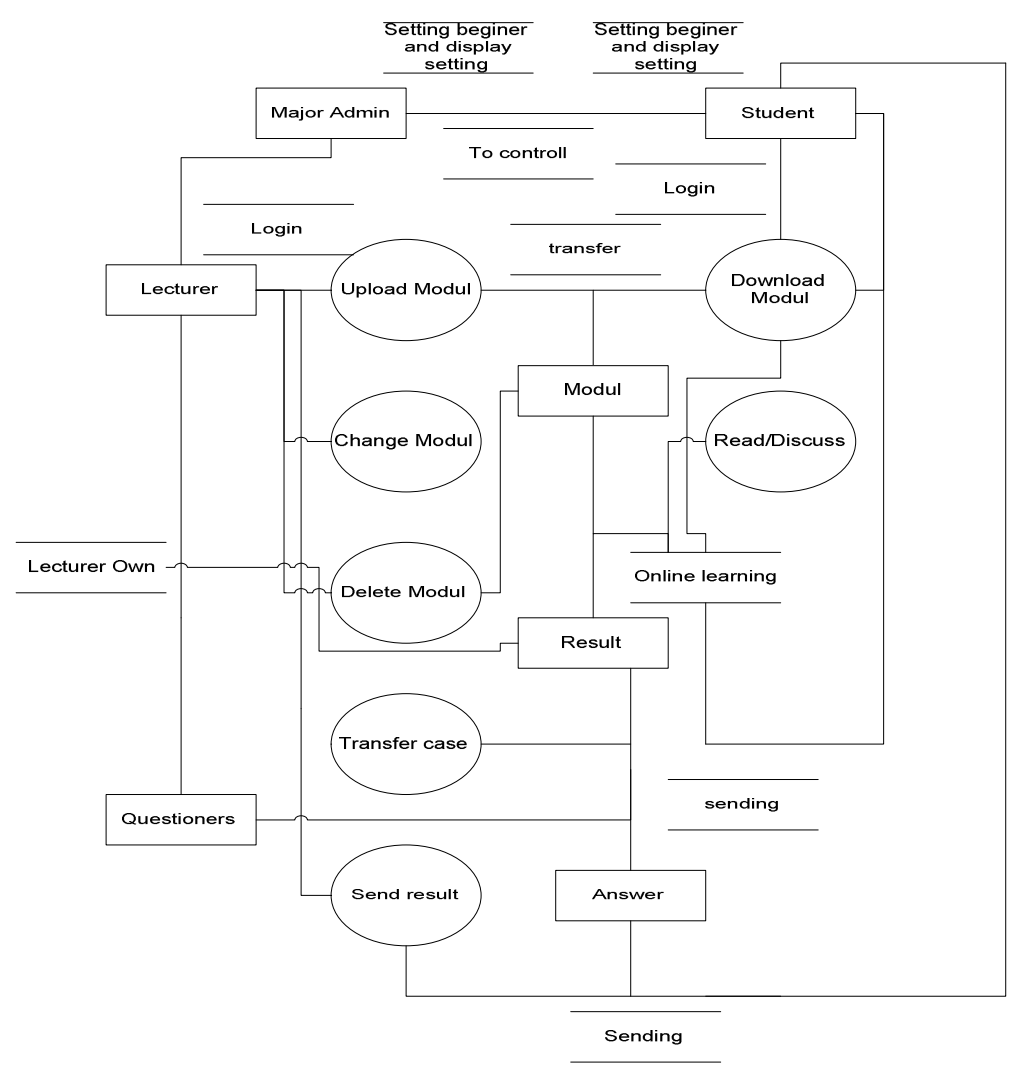

Figure 2. Data Flow Diagram 


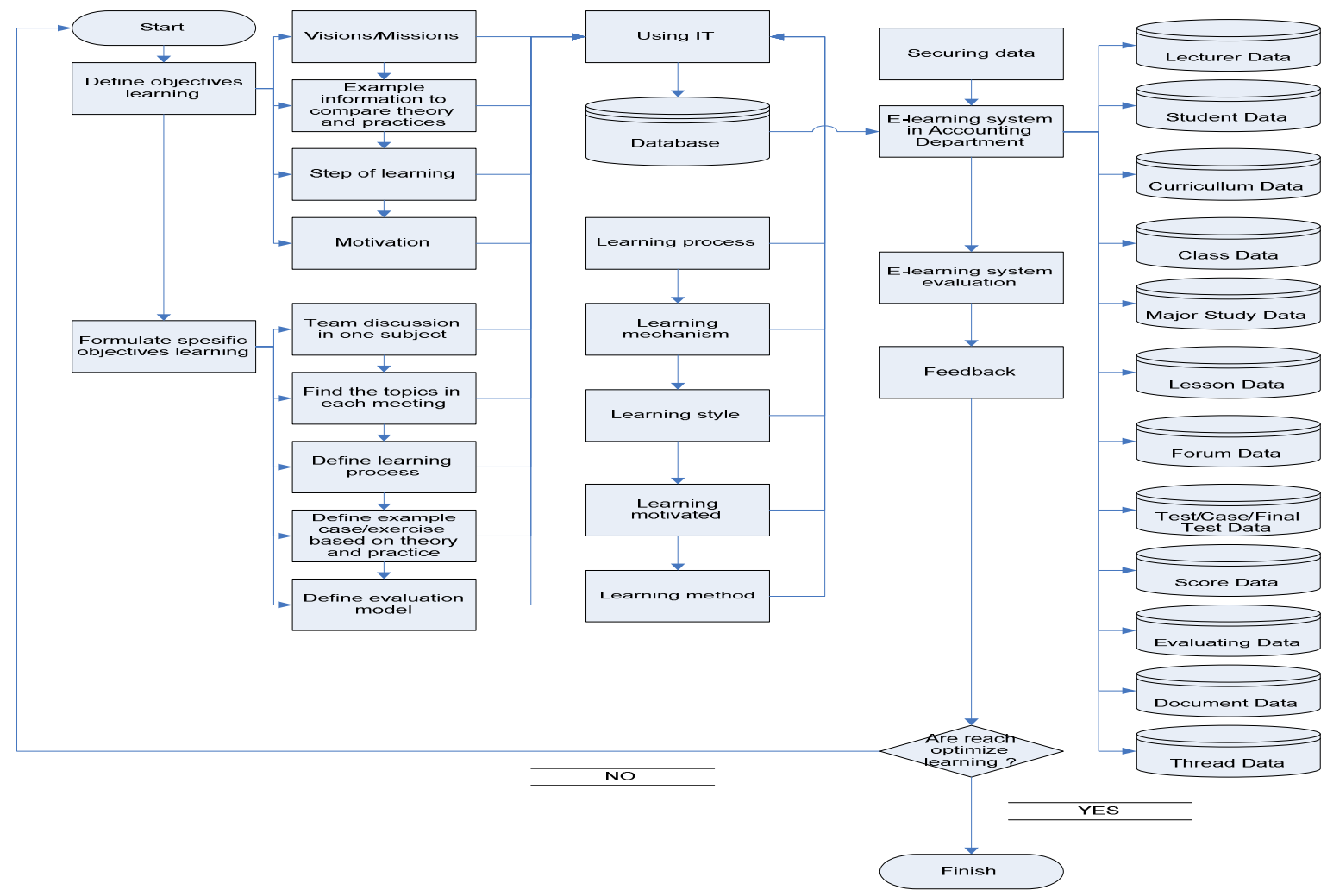

Figure 3. E-learning Model Accounting Department Airlangga University

namely GBPP, SAP, Syllabus, and Education Manual were closely related to the success of learning. Observational results of GBPP, SAP, Syllabus, and Education Manual appropriate to achieving output are summarized in Table 6.

The results of questionnaire administered to lecturers showed that as much as eight respondents very frequently used the Internet to search for information in order to support learning processes. In addition, $91.7 \%$ of them possessed e-mail addresses, which was expected to optimize elearning utilization. Lecturers, administration staff, and students as users were keys to e-learning success. Fulfilled requirement of infrastructure resource would facilitate installation to home Web site of Faculty Airlangga University that had already linked to faculties. About 90.2\% respondents have ever visited the Web site and utilized link facilities available in the university Web site.

\section{Designing of E-learning Model}

This stage was initiated by determining the content of e-learning. These materials would involve lecturers, administration staff, and students. Content of e-learning can be found in Table 7. Before the construction of e-learning model, Data Flow Diagram (DFD) was made first. This diagram can be found in Figure 3.

\section{E. E-learning Model of Accounting Department of Airlangga University}

This e-learning model could only be applied to Accounting Department due to adjustments to various demands. E-learning model of Accounting Department can be depicted in Figure 1.

Based on the above model, there were several stages of e-learning: E-learning-based planning of learning: (1). The stage of processes of learning, (2). The evaluation of the learning.

\section{CONCLUSION}

Conclusions that can be drawn from the present research, among others, are: The stages in the construction of e-learning model were initiated by the identification of organizational needs, users' needs, infrastructure and processes of learning and e-learning model for higher education institutions was different, according to their respective needs and characteristics. The constructed e-learning model only reflected the need for information system of Accounting Department of Airlangga University.

Suggestion provided in order to obtain adequate outcomes are: Strategies of direction priority and objectives of learning in Accounting Department need to be re-devised and then executed. Training of human resource and an integrated management information system must be the priorities, in addition to lecturers and students as users of e-learning, administration staff 
is highly desirable for the success of e-learning, lecturers as main sources of learning were obliged and must have e-mail and e-learning server needs to be supplemented in Accounting Department.

The constructed e-learning model shall be used as the basis for determining an e-learning model in a higher scope (faculty or university). The elearning model shall be flawless when it is translated into programming language or software.

\section{REFERENCES}

Agostinho, S. (2005). Naturalistic inquiry in e-learning research. International Journal of Qualitative Methods , 4 (1), 13-26.

Arifin, D. (2007). Pemanfaatan Teknologi Informasi dan Komunikasi dalam Dunia Pendidikan dan Bisnis. Dalam Berbagai Makalah Sistem Informasi. Bandung: Informatika.

Botturi, L., Cantoni, L., Lepori, B., \& Tardini, S. (2006). Fast prototyping as a communication catalyst for e-learning design. Dalam Making the transition to e-learning: Strategies and issues . Hershey: Information Science Publishing.

Dick, W., Carey, L., \& Carey, J. O. (2001). The systematic design of instruction. New York: Longman.

Effendi, E., \& Zhuang, H. (2005). E-learning Konsep dan Aplikasi. Yogyakarta: Andi.

Erdani, \& Yuliadi. (2007). Pengembangan Software Aplikasi Untuk Pendistribusian Diktat Kuliah. Dalam Berbagai Makalah Sistem Informasi. Bandung: Informatika.

Kurti, E. (2008). Students experiences on eMesimi: an e-learning system in University of Prishtina Kosova. Thesis, Växjö University, School of Mathematics and Systems Engineering .
Rosenberg. (2001). E-Learning. New York: McGrawHill.

Setiawan, D. (2005). Instructional Design dalam Pengembangan Media Electronic-Learning. Bandung: Informatika.

Siragusa, L. (2006). Quality eLearning: An instructional design model for online learning in higher education. Western Australian Institute for Educational Research Forum. Perth: Edith Cowan University.

Suryani, A. A. (2009). Pengembangan Model Information Technology (IT) Governance pada Organisasi Pendidikan Tinggi Menggunakan COBIT 4.1 Domain PO dan AI. Seminar Nasional Informatika (hal. 162-172). Yogyakarta: UPN Veteran.

The Herridge Group Inc. . (2004). The Use of Traditional Instructional Systems Design Models for eLearning. Uxbridge: The Herridge Group Inc. .

Triono, L. (2007). Urgensi Penggunaan Dan Pengembangan Teknologi Informasi Dalam Pendidikan (E-Learning). Skripsi, Universitas Pendidikan Indonesia, Program Studi Pendidikan Ilmu Komputer.

Wahid, \& Fahul. (2007). Pelajaran Dari Implementasi eLearning: Perspektif Difusi Inovasi. Dalam Berbagai Makalah Sistem Informasi. Bandung: Informatika.

Widodo. (2008). Kajian Metodologis Pengembangan Perangkat Lunak Pembelajaran. Dalam Makalah-Makalah Sistem Informasi. Bandung: Informatika.

Witanti, \& Wina. (2008). Teknologi Informasi yang Mendukung Pengelolaan Institusi Pendidikan. Dalam Makalah-Makalah Sistem Informasi. Bandung: Informatika. 